Bochenek M., A few remarks on the introduction of the term "marketing" into economic literature, „Ekonomia i Prawo. Economics and Law”, Polszakiewicz B., Boehlke J. (ed.), Vol. 14, No. 4/2015, pp. 401-413. DOI: http://dx.doi.org/10.12775/EiP.2015.026.

\title{
A FEW REMARKS ON THE INTRODUCTION OF THE TERM "MARKETING" INTO ECONOMIC LITERATURE
}

\author{
SUMMARY
}

Representatives of most academic disciplines, both at home and abroad, collect theoretical concepts developed by previous generations, thus creating histories of the sciences cultivated by them. In this respect, Polish academics engaged in marketing are lagging behind. The purpose of this study is to establish the "paternity" of the term "marketing". The authors of publications up to now have claimed that in 1912 this term, interpreted as market distribution, was introduced into the specialist literature by the American economist Arch Wilkinson Shaw. Meanwhile, after conducting studies of the literature, it has turned out that in 1890, and so 22 years earlier, the term "marketing" in the sense of introducing goods to the market was used by Alfred Marshall. So, it was this British economist who turned out to be the author of the above innovation in terminology in the field of economics.

Keywords: history of economic thought; beginnings of marketing; term "marketing" JEL Classification: B13; M31

Mirosław Bochenek, Nicolaus Copernicus University, Faculty of Economic Sciences and Management, Department of Economics, ul. Gagarina 13A, 87-100 Torun, Poland, phone: +48 5661148 96, e-mail: bochenek@econ.umk.pl. 


\section{INTRODUCTION}

The history of science has a centuries-old and rich tradition. Representatives of both those disciplines developed in antiquity and those developed in modern times deal with collecting, organising, and systematising earlier concepts, i.e. developing the history of their own achievements. These studies include, not only natural or technical sciences, but also the humanities. And so, there is a history of mathematics, astronomy, physics, chemistry, botany, and medicine, but also of philosophy, sociology, economics, psychology, etc. ${ }^{1}$.

The best-developed disciplines among the economic ones include the history of economic thought and the history of accounting. The first works devoted to the history of economics were developed in the first quarter of the $19^{\text {th }}$ century thanks to John Ramsey McCulloch² and Józef Maria HoeneWroński ${ }^{3}$. Monumental studies in this area include not only the works of foreign authors, i.e. Joseph Alois Schumpeter ${ }^{4}$ and Mark Blaug 5 , but also publications by Polish scientists, i.e. Edward Taylor ${ }^{6}$ and Wacław Stankiewicz ${ }^{7}$.

${ }^{1}$ For example, we can list studies synthesising all achievements, e.g. B. Suchodolski (ed.), Historia nauki polskiej, Vol. 1-9, Zakład Narodowy im. Os-solińskich - Wydawnictwo PAN, Wrocław 1970-1992; M. Iłowiecki, Dzieje nauki polskiej, Interpress, Warszawa 1981 or monographs on individual disciplines (in the series Historia nauki polskiej w monografiach published by the Polish Academy of Sciences in Kraków, dozens of studies by Polish historians of science have been published: Volume 1: E. Marczewski, Rozwój matematyki w Polsce, Kraków 1948; Volume 33: A. Klawek, Zarys dziejów teologii katolickiej w Polsce, PAU, Kraków 1949.

2 J.R. M'Culloch, A Discourse on the Rise, Progress, Peculiar Objects and Importance of Political Economy: containing an outline of a course of lectures on the principles and doctrines of that science, Printed for Archibald Constable and Co. - Hurst, Robinson, and Co. - G. and J. Robinson, Edinburgh - London - Liverpool 1824.

${ }^{3}$ J.M. Hoene-Wroński wrote his works containing a critical analysis of mercantilism, physiocratism, and Adam Smith's theory in 1803, but they were not published until 26 years after his death. J.M. Hoene-Wroński, Sept Manuscrits inédits, écrits de 1803 i 1806, Au Dépot des Ouvrages de L' Auteur, Paris 1879. In Polish, they appeared a few decades later: J.M. Hoene-Wroński, Mylne systemy ekonomji politycznej. Merkantylizm. Fizjokratyzm, Wydawnictwo M. Arcta, Warszawa 1911; J.M. Hoene-Wroński, System ekonomiczno przemystowy Adama Smitha. Wstęp do ekonomji politycznej, Wydawnictwo M. Arcta, Warszawa 1912.

${ }^{4}$ J.A. Schumpeter, Geschichte der Ökonomischen Analyse, Vandenhoeck \& Ruprecht, Göttingen 1965.

${ }_{5}$ M. Blaug, Teoria ekonomii. Ujęcie retrospektywne, PWN, Warszawa 1994.

${ }^{6}$ E. Taylor, Historia rozwoju ekonomiki, Vol. 1-2, PWN, Poznań 1957-1958; E. Taylor, Historia rozwoju ekonomiki, Vol. 3, NAKOM, Poznań 1991.

${ }^{7}$ W. Stankiewicz, Historia myśli ekonomicznej, PWE, Warszawa 2007. 
The oldest accounting records come from about 30 thousand years $\mathrm{BC}^{8}$, while accounting came into being only in the $15^{\text {th }}$ century AD. A few centuries later, the development of accounting became a subject of historical studies?.

Another scientific discipline that seeks to consolidate more and more theoretical achievements proved to be the science of management. Its history explores the regularity of the development of new concepts in the field of organisation and management ${ }^{10}$.

Although marketing is not a younger discipline than the science of management, the lack of such comprehensive studies in the native expert literature is noticeable. Even generally available marketing textbooks, by both Polish and foreign authors, lack even a superficial approach to the issues of the origins and development of marketing ideas ${ }^{11}$. The origin of marketing is also ignored in lexicographical studies ${ }^{12}$.

The purpose of this paper is not to present an outline of the development of marketing ideas, but only to attempt to determine the first use of the term "marketing" in the economic literature. The method of historical analysis has been applied.

\section{EXISTING VIEWS ON THE AUTHORSHIP OF THE TERM "MARKETING"}

Due to the standards adhered to in writing textbooks in this subject, ignoring historical issues, this task is not easy. From this point of view, the Marketing entry by Klemens Białecki included in Mata encyklopedia ekonomiczna (A Small Encyclopaedia of Economy) of 1974 should be considered

${ }^{8}$ S. Sojak, Księgowość analfabetów - wycinanie karbów, [in:] S. Sojak (ed.), Abacus — od źródet rachunkowości po wspótczesność, Wydawnictwo Naukowe Uniwersytetu Mikołaja Kopernika, Toruń 2014, p. 15.

9 E. Wojciechowski, Zarys rozwoju rachunkowości w dawnej Polsce, PWN, Warszawa 1964, p. 22 and next.

10 Z. Martyniak, Prekursorzy nauki organizacji i zarzadzania, PWE, Warszawa 1993, p. 7 and next.

${ }_{11}$ R. Głowacki, Z. Kossut, T. Kramer, Marketing, PWN, Warszawa 1984; L. Garbarski, I. Rutkowski, W. Wrzosek, Marketing, PWE, Warszawa 1992; L. Garbarski, I. Rutkowski, W. Wrzosek, Marketing. Punkt zwrotny nowoczesnej firmy, PWE, Warszawa 2000; L. Garbarski (ed.), Marketing. Kluczowe pojęcia i praktyczne zastosowania, PWE, Warszawa 2011;Ph. Kotler, Marketing, REBIS, Poznań 2005.

12 J. Altkorn, T. Kramer (eds.), Leksykon marketingu, PWE, Warszawa 1998; I. Kienzler, Leksykon marketingu, C.H. Beck, Warszawa 2008. 
as absolutely unique. K. Białecki argued that the term "marketing" has its origin in the English word market (in Polish rynek). Due to the lack of an adequate equivalent, the concept was adopted verbatim by other languages. According to the author of the marketing entry, the use of this word was for the first time discovered in the years 1906-1911. In the later period, the definition of marketing underwent evolution. Among the definitions provided by K. Białecki, those by R.S. Butler, P.T. Cherington and the Definitions Committee of the American Marketing Association are particularly noteworthy. The first of these scholars understood marketing as engaging factors in such combinations as will allow to carry out actions related to the sale or the activities supporting it. In the interpretation of the second scholar, however, marketing is the science of the distribution of goods from the producer to the consumer, which is not accompanied by a change in the form of production. In turn, the American Marketing Association defined marketing as a business activity related to the flow of goods and services from the manufacturer to the end user ${ }^{13}$. Also, in his study under the title $C z y$ "rozproszenie" marketingu ma wptyw na jego "tożsamosic"? (Does the "dispersion" of marketing affect its "identity"?, 2009), K. Białecki maintained that the first publications devoted to marketing issues were published in the period between 1906 and $1911^{14}$.

This condition caused among some representatives of marketing a "thirst" for historical considerations. It is particularly evident in the works of Adam Sagan and Jacek Kamiński. In his publication bearing the title Marketing w nazwach katedr $i$ zaktadów naukowych szkót wyższych w Polsce (Marketing concepts in the names of departments of economic universities in Poland, 2009), A. Sagan pointed out the need to establish, by those practising this discipline, their own myth of its beginning, and to systematise its constitutive thought as a condition for overcoming the crisis of identity of marketing ${ }^{15}$.

On the other hand, in the essay entitled Historyczna samosiwiadomośc marketingu (The Historical Self-Awareness of Marketing, 2010), J. Kamiński said that the first research on the history of marketing was undertaken mainly in the USA, already in the mid 1930s, and its results were presented in marketing magazines. The first of them, "Journal of Marketing", was founded

${ }^{13}$ K. Białecki, Marketing, [in:] K. Secomski (ed.), Mata encyklopedia ekonomiczna, PWE, Warszawa 1974, p. 436.

${ }^{14}$ K. Białecki, Czy „rozproszenie” marketingu ma wptyw na jego „tożsamośc”?, [in:] R. Niestrój (ed.), Tożsamość i wizerunek marketingu, PWE, Warszawa 2009, p. 15.

15 A. Sagan, Marketing w nazwach katedr i zaktadów naukowych szkót wyższych w Polsce, [in:] R. Niestrój (ed.), Tożsamość i wizerunek marketingu, PWE, Warszawa 2009, p. 137. 
in $1936^{16}$. J. Kamiński developed his considerations regarding historical issues in subsequent studies. In the article Dlaczego marketingowi potrzebne sq badania historyczne (Why does marketing need historical studies), 2010, he drew attention to the close relationship between marketing identity and its history, and pointed to negligence in conducting research into the history of marketing, which required urgent supplementation. J. Kamiński also regretted that in comparison with other social sciences, such as economics, sociology and management, marketing refers to the achievements of scientists who have contributed to its creation to a very small extent. Textbooks present only the development of this discipline as evolution of the concept of doing business. The starting point was the concept of production, which was displaced by the concept of the product and sale, which, in turn, was replaced by the concept of marketing. However, the views of luminaries of the discipline are overlooked. As a result, the achievements of developers of marketing are presented in a much different way than in other sciences. J. Kamiński advocated the resumption of research into the development of marketing ideas ${ }^{17}$. Analyzing the causes that block historical research, he wrote: "Low interest in the history of marketing and the marketing philosophy of the earlier thinkers also undoubtedly stems from the close proximity in time (marketing literature emerged in the early $20^{\text {th }}$ century), and from the fact that the developers of marketing could hardly be regarded as the real representatives of marketing, because they were just economists"18. According to the author of the quoted historical article, marketing research is also important for its legitimacy as a science. In this regard Kamiński stated: "Historical presentation of the issues undertaken in science contributes to its legitimising, and provides it with credibility and 'scientificalness'. Therefore, diagnosing its own origins is the duty of every science. It is hard to imagine a scientific discussion which dispenses with references to historical sources. A. Sagan is right when he says that 'marketing, like any other discipline, should contain in itself an appropriate myth of origin and answer the questions where we came from, and what is the history of the thought that constitutes the field of marketing"'19. J. Kamiński took the view that the science of marketing was almost a hundred years old. He linked the birth of this science with the historical school, and put it this way: "The science referred to as marketing emerged in the ear-

${ }^{16}$ J. Kamiński, Historyczna samoświadomość marketingu, "Marketing i Rynek", Vol. 10/2010, p. $2 ; 4$.

17 J. Kamiński, Dlaczego marketingowi potrzebne sq badania historyczne, "Marketing i Rynek", Vol. 4/2010, pp. 2-3.

18 Ibidem, p. 3.

${ }^{19}$ Ibidem, p. 4. 
ly $20^{\text {th }}$ century heavily influenced by the historical approach to economics, often associated with the achievements of the German historical school. From the fact that the developers of marketing were primarily economic historians, it resulted that the historical approach was the methodological basis on which they built marketing rules" 20 .

J. Kamiński also devoted his article under the title On A.W. Shaw's "Some Problems in Market Distribution" on the hundredth anniversary of the first scientific study on marketing, 2012, to the the beginnings of scientific marketing. The appearance of Arch Wilkinson Shaw's publication was, according to J. Kamiński, recognised as an event marking the foundation of marketing. It was decided by the fact that he had developed a system of scientific reflection on marketing and thus, thanks to him, a specific object of study was isolated from related disciplines. This means that A.W. Shaw created a new system of organised knowledge. J. Kamiński thought it significant that although in the said article on Some Problems in Market Distribution, issued in 1912, A.W. Shaw repeatedly used the term "marketing", he still used the term "market distribution" in the title. This was due to the fact that at that time marketing activities were interpreted as market distribution, i.e. they were synonymous terms. Delineating the scope of marketing interests, A.W. Shaw pointed out that entrepreneurs should not limit their field of vision and action only to production, but also take an interest in the distribution of goods, prices, differentiation of products, sales methods, consumers' needs, demand management, marketing communications, advertising, market analysis on different planes, economic and social classes, as well as marketing research. These issues comprise the scope of interest of the then marketing. Thus, A.W. Shaw pointed out the neglect of supplying customers with products and the need to catch up on the backlog. Thus, he appointed for marketing a task to efficiently solve the problems of distribution based on systematic scientific research, using the achievements of economics and psychology. At the same time, J. Kamiński accepted the stance of other authors, including R. Bartels, that the term "marketing" was used for the first time in the years 1906-1911 as the name of the marketing science classified as a branch of applied economics. He also stressed that the term had functioned in popular circulation already a few decades earlier in the meaning of an exchange activity undertaken on the market. Even Miss Parlo's New Cook Book and Media Guide, which was in circulation since 1880, attested to this fact. However, according to W. Lazer (Some Observations on Development on Marketing Thought,

${ }^{20}$ Ibidem, p. 6. The cited author promoted the same position in another work. J. Kamiński, Historyczna samoświadomośc..., op. cit., p. 2. 
1979), the term "marketing" in the sense of a market practice was used as early as in 1856. On the other hand, Webster's Universal Dictionary dates the first use of this term to 1561. Despite these numerous findings about the introduction of the term of "marketing", J. Kamiński did include A.W. Shaw among the precursors of marketing ${ }^{21}$.

Since marketing, as rightly pointed out by Jerzy Dietl in his work under the title Dylematy badan wspótczesnego marketingu (Dilemmas of Contemporary Marketing Research), 2001, grew out of economics ${ }^{22}$, the author of this study took the liberty, as he represents, of the theory and history of economics, shortly supplementing the discussion about the introduction of the term of "marketing" into scientific economic literature.

According to the authors cited above, Arch Wilkinson Shaw did use the term "marketing" in his work Some Problems in Market Distribution, which originally appeared on the pages of "Quarterly Journal of Economics" in 1912, and in an extended version as a separate book publication in 1951. In the book comprising 119 pages, A.W. Shaw used this term 8 times $^{23}$.

Unfortunately, the above innovation in terminology should not be attributed to the author of Some Problems in Market Distribution, since he had been forestalled by the British economist Alfred Marshall by 22 years. What is more, A.W. Shaw was familiar with A. Marshall's publication, as evidenced by the footnote provided by A.W. Shaw in the first chapter of the cited work $^{24}$. This means that the American economist borrowed the analysed term from the British economist.

\section{ALFRED MARSHALL'S INNOVATION IN TERMINOLOGY}

Alfred Marshall was one of the most original and prolific British economists. Although he was not the founder of the neoclassical school, he developed a new comprehensive system of theoretical economics, and dominated and proved to be the most influential co-founder of this school, and the subjective-marginal movement. He was often called the "head" of the

${ }^{21}$ J. Kamiński, O „Niektórych problemach dystrybucji rynkowej” A.W. Shawa w setnq rocznice pierwszego naukowego opracowania na temat marketingu, "Marketing i Rynek", Vol. 2/2012, pp. 2-8.

${ }^{22}$ J. Dietl, Dylematy badań wspótczesnego marketingu, "Marketing i Rynek", Vol. 3/2001, p. 8.

${ }^{23}$ A.W. Shaw, Some Problems in Market Distribution. Illustrating the application of a basic philosophy of business, Harvard University Press, Cambridge, Massachusetts 1951, pp. 16; 18; 20; $32 ; 41 ; 42 ; 50 ; 54$.

${ }^{24}$ Ibidem, p. 24. 
neoclassical school. Born in 1842 in Clapham (today in London), he studied philology and mathematics at St. John's College, Cambridge. In 1868 he took the chair of moral sciences specially created for him, and began to lecture on logic, philosophy and economics. Nine years later, he was appointed professor of political economy and vice-chancellor of the newly founded University College in Bristol. In 1882, he became professor of political economy at Balliol College, Oxford, and in 1885 he was appointed professor of political economy at King's College, Cambridge. There he created his own school called "the Cambridge School", and educated a significant circle of successors who developed his thoughts. Among others, they included: A.C. Pigou, J.M. Keynes and J.V. Robinson. In 1890, he co-founded, together with F.Y. Edgeworth, the British Economic Association, which was later transformed into the Royal Economic Society. In 1908, he resigned from his university post. He died in 1924, in Cambridge. A. Marshall's most important publications include: The Economics of Industry (co-author: M. Paley, 1879), Principles of Economics (1890), Some Aspects of Competition (1890), Elements of Economics of Industry (1892), The New Cambridge Curriculum in Economics and Associated Branches of Political Science (1903), Official Papers (1903), Industry of Trade (1918), Money, Credit and Commerce (1923) Memorials (posthum., 1925), and The Pure Theory of Foreign Trade. The Pure Theory of Domestic Values (1879, posthum., 1930).

Both in the work Economics of Industry as well as in the treatise under the title Principles of Economics, A. Marshall introduced original terms and concepts, and called for a modification of the earlier name of political economy. He believed that the simple term "economics" better reflects its content and, therefore, the commonly used name "political economy" should be rejected ${ }^{25}$. He advocated the use of the marginal analysis method and the method of partial equilibrium, and supported the use of geometry in economics ${ }^{26}$. Although A. Marshall was not the first economist using the one-word name of "economics", it was due to him that this term quickly spread throughout the Englishspeaking countries, and he is customarily credited with this innovation.

According to A. Marshall, the central issue of economics is the analysis of supply and demand. Market becomes the basic category of this analysis. As a result of interaction between supply and demand, a tendency to estab-

25 A. Marshall, M. Paley Marshall, The Economics of Industry, Macmillan and Co., London 1879, pp. 2-5; A. Marshall, Principles of Economics, Macmillan, London 1947, pp. 1-53 (Polish edition: A. Marshall, Zasady ekonomiki, M. Arcta, Warszawa 1925-1928, pp. 1-50).

26 A. Marshall, Zasady..., op. cit., pp. 35-44; 269-285, A. Marshall, Principles..., op. cit., pp. 38-47; 770-783. 
lish a uniform price for each commodity emerges on the market. The author of Principles of Economics used the theory of marginal utility to explain demand. The basic determinants of demand include the utility and income which the consumer has. In order to determine a person's demand for given goods, it is necessary to list the prices of those goods. Demand is the quantity of given goods demanded by the consumer at a given price. Therefore, demand is a function of the price. The author of Principles of Economics understood supply as the quantity of goods offered for sale. In the analysis of supply A. Marshall assumed that it depends entirely on the price of the given goods. He used the theory of production costs associated with the theory of marginal productivity to explain supply. As part of cash costs, the British economist distinguished total costs, which he in turn divided into fixed and variable ones. $\mathrm{He}$ also considered marginal costs. Including the "theory of long and short business cycles" in the cost analysis, A. Marshall argued that the possibilities of changing production volumes depending on the time needed to adapt should be investigated. This theory, which enabled the author of Principles of Economics to boost economic analysis, is considered as one of his most important scientific achievements. He considered an enterprise as a "representative company", treating it as a miniature image of the entire industry. The analysis of the impact that industry has on a company led the British economist to the discovery of external advantages (benefits) and disadvantages, which are nothing else but "positive externalities" and "negative externalities". Positive externalities supply benefits to other entities, while negative externalities cause them damage. In a market where there is free competition, as a result of the interaction of supply, demand and prices, a temporary balance ("equilibrium") is established. In the conditions of this balance, marginal utility is levelled with marginal difficulty and waiting. Market equilibrium emerges at the intersection of the demand curve and the supply curve. This point marks the volume that corresponds to equilibrium $q_{0}$, and the market equilibrium price $p_{0}$, which is the price at which the volume offered finds buyers. The price is decided neither by demand nor by supply separately. These two categories affect the price level at the same time. In the short period, demand may have a stronger impact, while in the long period supply will have a greater influence due to the possibility of adjusting production costs and volume, and even the size and branch of the enterprise, to the size of demand $^{27}$.

27 A. Marshall, Zasady..., op. cit., Vol. 1: pp. 20-24; 82-134; 310-375; Vol. 2: pp. 312-322; 354-383; A. Marshall, Principles..., op. cit., pp. 18-26; 83-136; 323-393; 805-812; 838-858. 


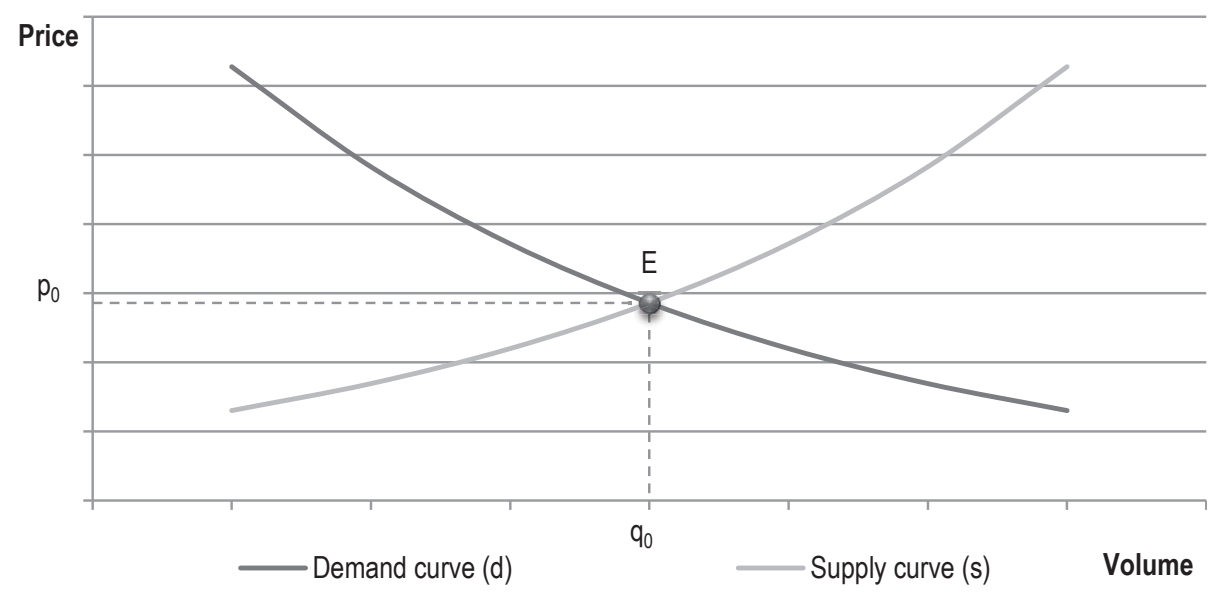

Figure 1. Single market equilibrium

Source: Own preparation.

A. Marshall considered the term "marketing" in two books of the Principles of Economics, i.e. in Book Four and Five. In Book Four he elaborated on the factors of production. Alongside the traditional triad which includes land, labour and capital, the author of Principles of Economics also distinguished organisation. In his view, when skilfully used, this factor of production helps to increase productivity. A. Marshall emphasised the importance of the division of labour, the increased use of machinery, the concentration and location of industries, the management of companies, and the production volumes of enterprises for the increase in social wealth. Establishing and running a larger enterprise requires from its executives increased efforts, skills, as well as permanent rivalry with its competitors. Without originality, initiative, perseverance, tact or luck in business, an enterprise's growth is impossible. A condition for the successful development of an enterprise is not only an increase in production, which brings economies of scale, but also an expanding of the markets. Marshall counted external and internal advantages (benefits) among the economies of scale. External benefits are determined by overall economic development, whereas internal benefits depend on the means available to individual enterprises. Most internal benefits come from production on a large scale. These benefits result from a better use of special machines, the introduction of new machines, manufacturing new products, offering discounts on wholesale purchases, a better selection of managers and specialised masters and foremen, taking out secure loans and solving the problem of sales thanks to spending on advertising. The introduction of goods on the market, or marketing, is not made difficult in industries that produce simple 
and homogeneous goods on a massive scale, and have conquered large markets. In contrast, marketing is much more difficult in the case of the production of special products, which are manufactured with the intention of meeting existing needs in new ways, or creating new needs ${ }^{28}$.

In Book Five, A. Marshall dealt with the relationships that occur between supply and demand, and price. In this part of the monumental work, his considerations were related to total costs, marketing costs, insurance against risks, and the costs of reproduction. Analysing some of the costs of functioning of an enterprise, he said that the introduction of goods on the market, or marketing, requires taking additional action and bearing the costs which depend on the type of product, the method of manufacturing it, and the distance between the place of production and the sales market ${ }^{29}$. The author of Principles of Economics wrote: "There are two elements of the general expenses of a business, the sharing of which between the different branches requires some special attention. They are the expense of marketing and that of insurance against risk. Some kinds of goods are easily marketing; there is a steady demand for them, and it is always safe to make them for stock. But for that very reason competition cuts their price 'very fine', and does not allow a large margin above the direct cost of making them. Sometimes the tasks of making and selling them can be rendered almost automatic, so as to require very little to be charged on their account under the heads of the expenses of management and marketing. But in practice it is not uncommon to charge such goods with even less than the small share that would properly fall to them, and to use them as a means of obtaining and maintaining a business connection, that will facilitate the marketing of other classes of goods, the production of which cannot so well be reduced to routine; for as to these there is not so close a competition. (...) Economic progress is constantly offering new facilities for marketing goods at a distance: it not only lowers cost of carriage, but what is often more important, it enables producers and consumers in distant places to get in touch with one another. In spite of this, the advantages of the producer who lives on the spot are very great in many trades; they often enable him to hold his own against competitors at a distance whose methods of production are more economical. He can sell in his own neighbourhood as cheaply as they can, because thought the cost

\footnotetext{
${ }_{28}$ A. Marshall, Zasady..., op. cit., Vol. 1: pp. 135-302; A. Marshall, Principles..., op. cit., pp. 138-313.

${ }_{29}$ A. Marshall, Zasady..., op. cit., Vol. 1: pp. 310-479; A. Marshall, Principles..., op. cit., pp. 323-503.
} 
of making is greater for his goods than for theirs, he escapes much of the cost which they incur for marketing" ${ }^{30}$.

\section{CONCLUSIONS}

It follows from the analysis of the aforementioned fragments of A. Marshall's monumental work under the title Principles of Economics that perhaps the first economist who introduced the term "marketing" to the scientific literature was indeed A. Marshall. He understood "marketing" as the decisions and actions aimed at introducing a product on the market. What is more, the findings of this study also demand the rejection of the arguable notion of a strong relationship between marketing and the German historical school. Marketing emerged from the neo-classical school belonging to the subjectivemarginal movement, which was dominated by the microeconomic approach, and whose central category was the market and individual business entities such as the enterprise and the household.

\section{BIBLIOGRAPHY}

Altkorn J., Kramer T. (eds.), Leksykon marketingu, PWE, Warszawa 1998.

Białecki K., Czy ,rozproszenie" marketingu ma wptyw na jego „tożsamośc"?, [in:] R. Niestrój (ed.), Tożsamośc i wizerunek marketingu, PWE, Warszawa 2009.

Białecki K., Marketing, [in:] K. Secomski (ed.), Mata encyklopedia ekonomiczna, PWE, Warszawa 1974.

Blaug M., Teoria ekonomii. Ujęcie retrospektywne, PWN, Warszawa 1994.

Dietl J., Dylematy badań wspótczesnego marketingu, "Marketing i Rynek", Vol. 3/2001. Garbarski L. (ed.), Marketing. Kluczowe pojęcia i praktyczne zastosowania, PWE, Warszawa 2011.

Garbarski T., Rutkowski I., Wrzosek W., Marketing, PWE, Warszawa 1992.

Garbarski T., Rutkowski I., Wrzosek W., Marketing. Punkt zwrotny nowoczesnej firmy, PWE, Warszawa 2000.

Głowacki R., Kossut Z., Kramer T., Marketing, PWN, Warszawa 1984.

Hoèné-Wroński J.M., Sept manuscrits inédits, écrits de 1803 j 1806, Au Dépot des Ouvrages de L'Auteur, Paris 1879.

${ }^{30}$ A. Marshall, Zasady..., op. cit., Vol. 1: pp. 377-379; A. Marshall, Principles..., op. cit., pp. 396-398. While translating the work by the British economist, Czesław Znamierowski translated the word marketing as a sale of goods, retailing or delivering goods on the market. 
Hoene-Wroński J.M., Mylne systemy ekonomji politycznej. Merkantylizm. Fizjokratyzm, M. Arcta, Warszawa 1911.

Hoene-Wroński J.M., System ekonomiczno przemystowy Adama Smitha. Wstęp do ekonomji politycznej, M. Arcta, Warszawa 1912.

Iłowiecki M., Dzieje nauki polskiej, Interpress, Warszawa 1981.

Kamiński J., Dlaczego marketingowi potrzebne sa badania bistoryczne, "Marketing i Rynek", Vol. 4/2010.

Kamiński J., Historyczna samoświadomośc marketingu, "Marketing i Rynek", Vol. 10/2010.

Kamiński J., O „Niektórych problemach dystrybucji rynkowej” A.W. Shawa w setnq rocznice pierwszego naukowego opracowania na temat marketingu, "Marketing i Rynek", Vol. 2/2012.

Kienzler I., Leksykon marketingu, C.H. Beck, Warszawa 2008.

Klawek A., Zarys dziejów teologii katolickiej w Polsce, PAU, Kraków 1949.

Kotler Ph., Marketing, REBIS, Poznań 2005.

M'Culloch J.R., A Discourse on the Rise, Progress, Peculiar Objects and Importance of Political Economy: containing an outline of a course of lectures on the principles and doctrines of that science, Printed for Archibald Constable and Co. - Hurst, Robinson, and Co. - G. and J. Robinson, Edinburgh - London - Liverpool 1824.

Marczewski E., Rozwój matematyki w Polsce, PAU, Kraków 1948.

Marshall A., Paley M., The Economics of Industry, Macmillan and Co., London 1879.

Marshall A., Principles of Economics, Macmillan, London 1947.

Marshall A., Zasady ekonomiki, M. Arcta, Warszawa 1925-1928.

Martyniak Z., Prekursorzy nauki organizacji i zarzadzania, PWE, Warszawa 1993.

Sagan A., Marketing w nazwach katedr i zaktadów naukowych szkót wyższych w Polsce, [in:] R. Niestrój (ed.), Tożsamośc i wizerunek marketingu, PWE, Warszawa 2009.

Schumpeter J.A., Geschichte der Ökonomischen Analyse, Vandenhoeck \& Ruprecht, Göttingen 1965.

Shaw A.W., Some Problems in Market Distribution. Illustrating the application of a basic philosophy of business, Harvard University Press, Cambridge, Massachusetts 1951.

Sojak S., Księgorwość analfabetów — wycinanie karbórw, [in:] S. Sojak (ed.), Abacus — od źódet rachunkowości po wspótczesnośc, Wydawnictwo Naukowe Uniwersytetu Mikołaja Kopernika, Torun 2014.

Stankiewicz W., Historia myśli ekonomicznej, PWE, Warszawa 2007.

Suchodolski B. (ed.), Historia nauki polskiej, Vol. 1-9, Zakład Narodowy im. Ossolińskich - Wydawnictwo PAN, Wrocław 1970-1992.

Taylor E., Historia rozwoju ekonomiki, Vol. 1-2, PWN, Poznań 1957-1958.

Taylor E., Historia rozwoju ekonomiki, Vol. 3, NAKOM, Poznań 1991.

Wojciechowski E., Zarys rozwoju rachunkowości w dawnej Polsce, PWN, Warszawa 1964. 
